\title{
大日本寗業協會雑誌
}

第 $\quad 4 \quad 4$ 集 第 524 號

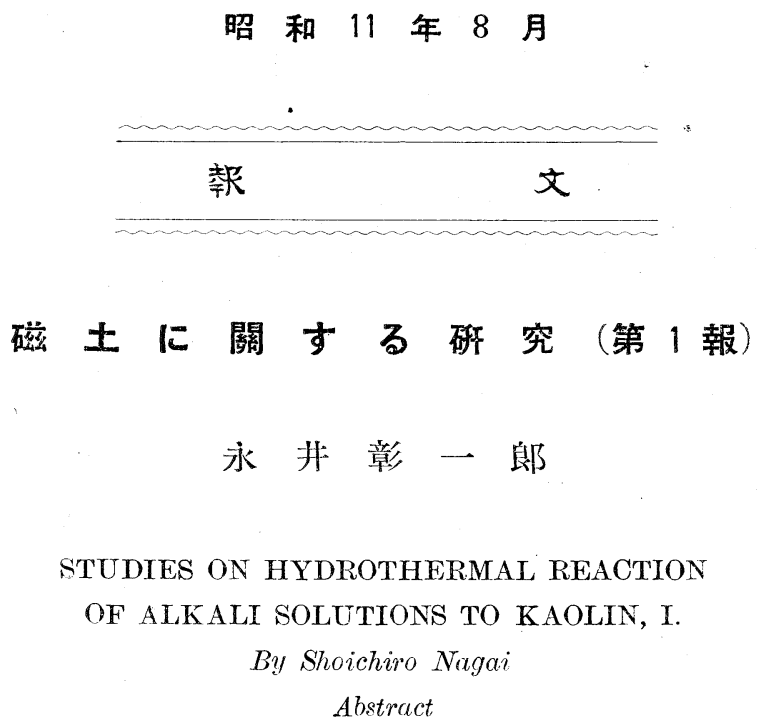

There are considerabiy large numbers of reports of studies on kaolinite and kaolin heretofore, and it seems no more to be necessary to add the study on this point. But it is relatively scarce to see the studies on hydrothermal reaction of alkali solutions to kaolinite or kaolin. The author is now studying on the hydrothemal reactions of alkali solutions to various clayey substances and reported some results (Journ. Soc. Chem. Ind., Japan, 1932, 35, 182B, 257B, 354B; 1985, 38, $371 \mathrm{~B}, 732 \mathrm{~B} ; 1936,39,7 \mathrm{~B}, 45 \mathrm{~B}, 96 \mathrm{~B}$, etc.). Some results of studies on the hydrothermal reaction of alkali solutions to kaolinite or kaolin were' reported in the present paper, which is briefly abstracted from the original Japanese communication, as following:

(1) Three kaolinite samples from Korea and one sample of the purest kaolin "Zettlit $z$ kaolin" were first analysed and obtained the resuls shown in the following table 1.

Table 1. Chemical Compositions of Kaolinite and Kaolin Samples

\begin{tabular}{|c|c|c|c|c|c|c|c|c|c|}
\hline $\begin{array}{l}\text { Sign of } \\
\text { Sample }\end{array}$ & $\begin{array}{l}\text { Kind and Or } \\
\text { of Sample }\end{array}$ & rigin & $\begin{array}{l}\text { Loss on } \\
\text { Ignition }\end{array}$ & $\mathrm{SiO}_{2}$ & $\mathrm{Al}_{2} \mathrm{O}_{3}$ & $\mathrm{Fe}_{2} \mathrm{O}_{3}$ & $\mathrm{CaO}$ & $\mathrm{MgO}$ & Total \\
\hline $\mathrm{Al}_{2} \mathrm{C}$ & $\mathrm{O}_{3} \cdot 2 \mathrm{SiO}_{2} \cdot 2 \mathrm{H}_{2} \mathrm{O}$ & Theoret & $13.96 \%$ & $46.51 \%$ & $39.53 \%$ & & - & - & $100.00 \%$ \\
\hline (A) & Kaolinite from & Korea & 14.01 & 46.10 & 39.44 & trace & 0.53 & trace & 100.08 \\
\hline (B) & "I. & "1 & 14.30 & 45.92 & 39.10 & 0.54 & trace & trace & 99.86 \\
\hline (C) & " & "1 & 14.81 & 45.22 & 38.72 & 0.43 & trace & trace & 99.18 \\
\hline (D) & Zettlitz Kaolin & & 13.61 & 46.18 & 39.03 & 0.17 & 0.40 & 0.40 & 99.79 \\
\hline
\end{tabular}

(2) The sample (D) of Zettlitz kaolin was first calcined at various temperatures for severai hours, and this calcined kaolinor meta-kaolin was analysed its insoluble and soluble parts by treating with $10 \% \mathrm{NaOH}$ and then $5 \% \mathrm{HCl}$ solutions. The moleclar ratios of (a) calcined loss or the amount 
of water set free by the calcination and (b) dissolved alumina in HCl solution to dissolved silica in $\mathrm{NaOH}$ solution, and the specific gravities were determined to discuss the ordinary thermal decomposition of kaolinite and the soluble parts of calcined products, is shown in the following table

Table 2. Comparative Tests of Calcination of Kaolin at Various Temperature

\begin{tabular}{|c|c|c|c|c|c|c|c|c|c|c|c|}
\hline \multicolumn{2}{|c|}{$\begin{array}{l}\text { Calcining } \\
\text { Condition }\end{array}$} & \multirow{2}{*}{\multicolumn{2}{|c|}{$\begin{array}{l}\text { Calc- Insolu- } \\
\text { ining ble } \\
\text { Loss Residue }\end{array}$}} & \multicolumn{5}{|c|}{ Dissolved Parts } & \multirow{2}{*}{$\begin{array}{l}\text { Molar Ra- } \\
\text { tio of Dis- } \\
\text { solv. } \\
\mathrm{Al}_{2} \mathrm{O}_{3} \text { to } \\
\text { Calc. Loss }\end{array}$} & \multirow{2}{*}{$\begin{array}{l}\text { Molar ra- } \\
\text { tio of Dis- } \\
\text { solv. } \mathrm{Al}_{2} \mathrm{O}_{3} \\
\text { to Dissolv. } \\
\mathrm{SiO}_{2}\end{array}$} & \multirow{2}{*}{$\begin{array}{l}\text { Specific } \\
\text { Gravity }\end{array}$} \\
\hline Temp. T & Time & & & $\overparen{\mathrm{SiO}_{2}}$ & $\mathrm{Al}_{2} \mathrm{O}_{3}$ & $\mathrm{Fe}_{2} \mathrm{O}_{3}$ & $\mathrm{CaO}$ & Total & & & \\
\hline $400^{\circ} \mathrm{C}$ & $2 \mathrm{Hr}$ & s $1.74 \%$ & $71.86 \%$ & $9.58 \%$ & $6.99 \%$ & $0.43 \%$ & $0.36 \%$ & $17.36 \%$ & 0.70 & 0.43 & 2.623 \\
\hline 550 & 2 & 12.57 & 19.64 & 38.69 & 35.48 & 0.68 & 0.35 & 74.60 & 0.44 & 0.55 & $\longrightarrow$ \\
\hline 800 & 4 & 13.42 & 17.20 & 40.96 & 38.28 & 0.73 & 0.34 & 80.31 & 0.44 & 0.55 & - \\
\hline 850 & 4 & 13.53 & 12.10 & 44.74 & 40.00 & 0.98 & 0.39 & 86.11 & 0.45 & 0.58 & - \\
\hline 900 & 2 & 13.70 & 13.43 & 43.15 & 39.41 & 0.98 & 0.93 & 84.47 & 0.44 & 0.54 & 2.685 \\
\hline 900 & 4 & 13.79 & 18.55 & 39.13 & 38.68 & 0.78 & 0.67 & 79.24 & 0.43 & 0.58 & $\therefore$ \\
\hline 1100 & 2 & 13.74 & 29.63 & 51.82 & 18.92 & 0.78 & 0.69 & 72.21 & 0.21 & 0.22 & 2.693 \\
\hline 1260 & 2 & 14.00 & 53.38 & 40.88 & 4.74 & 0.74 & 0.52 & 46.88 & 0.05 & 0.07 & $\ldots$ \\
\hline 1300 & 1 & 14.45 & 62.21 & 33.98 & 4.02 & 0.55 & 0.66 & 39.21 & 0.04 & 0.07 & 2.689 \\
\hline 1400 & 1 & 14.72 & 73.45 & 24.30 & 3.21 & 0.44 & 0.65 & 28.60 & 0.03 & 0.08 & 2.678 \\
\hline 1500 & 1 & 15.03 & 76.37 & 22.85 & 2.30 & 0.52 & 0.60 & 26.27 & 0.08 & 0.06 & 2.681 \\
\hline
\end{tabular}

From these results, it is clearly seen that the calcination at $850-900^{\circ} \mathrm{C}$ is most effective to dissolve the largest amounts of silica and alumina, and also to make the smallest amount of insoluble residue.

(3) Some samples of these calcined kaolin were treated with $30 \% \mathrm{NaOH}$ solution in an autoclave under the pressure $\left(20 \mathrm{~kg} / \mathrm{cm}^{2}\right)$ of saturated steam vapour (about $210^{\circ} \mathrm{C}$ )for 1 hour. By filtering the reacted solution, the product insoluble in the alkali solution was obtained in the amount of about 120-130\%. This amount is larger than the originally used calcined kaolin, showing the fact that the calcined kaolin or meta-kaolin $\left(\mathrm{Al}_{2} \mathrm{O}_{3} \cdot 2 \mathrm{SiO}_{2}\right)$ catches water to the original kaolin $\mathrm{Al}_{2} \mathrm{O}_{3} \cdot 2 \mathrm{SiO}_{2} \cdot 2 \mathrm{H}_{2} \mathrm{O}$, or catches alkalj or both alkali and water to make alkali alumino-sillicate or its hydate $\mathrm{Na}_{2} \mathrm{O} \cdot \mathrm{Al}_{2} \mathrm{O}_{3} \cdot 2 \mathrm{SiO}_{2}$ or $\mathrm{Na}_{2} \mathrm{O} \cdot \mathrm{Al}_{2} \mathrm{O}_{3} \cdot 2 \mathrm{SiO}_{2} \cdot \mathrm{nH}_{2} \mathrm{O}$, etc. This product was seen to be easily soluble in dilute alkali and acid, and composed principally by $\mathrm{Na}_{2} \mathrm{O}, \mathrm{Al}_{2} \mathrm{O}_{3}, \mathrm{SiO}_{2}$ and $\mathrm{H}_{2} \mathrm{O}$, having the rational formula of alkali alumino-hydr-silicate $\mathrm{Na}_{2} \mathrm{O} \cdot \mathrm{Al}_{2} \mathrm{O}_{3} \cdot 2 \mathrm{SiO}_{2} \cdot \mathrm{nH}_{2} \mathrm{O}$, as above presumed. The results of analyses of the products and the calculated rational formulae are shown in the following table.

Table 3. Tests of Hydrothermal Reaction Products of Alkali Solution on Calcined Kaolin

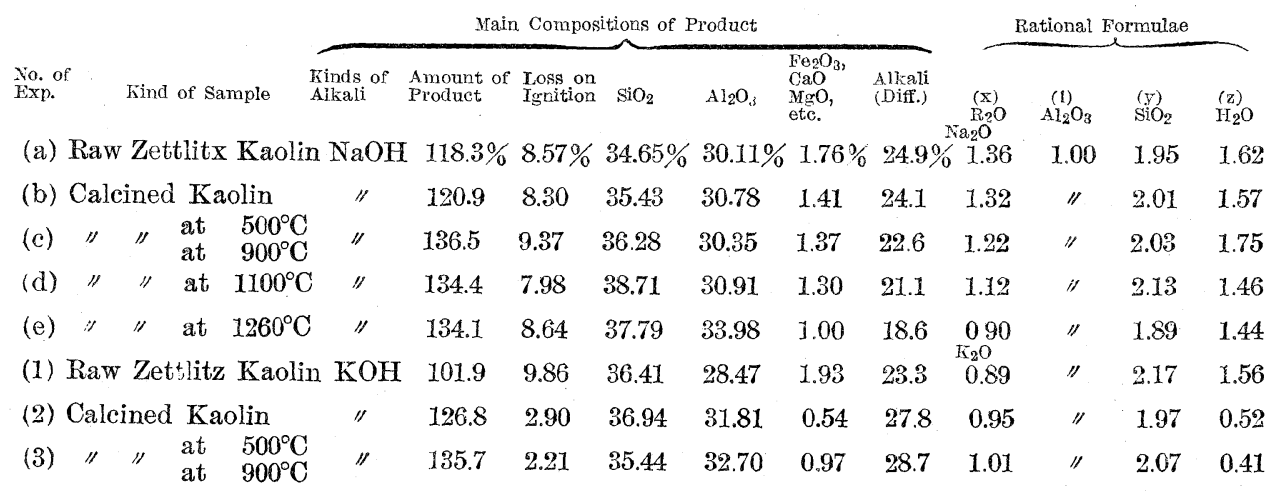


From these results, the following points are to be discussed. (1) Calcined kaolin produces the same product, alkali alumino-hydro-silicate $\mathrm{R}_{2} \mathrm{O} \cdot \mathrm{Al}_{2} \mathrm{O}_{3} \cdot 2 \mathrm{SiO}_{2} \cdot \mathrm{nH} \mathrm{H}_{2} \mathrm{O}$, as that from the raw kaolin, (2) This product from $\mathrm{NaOH}$ solution has larger amount of combined water than that from $\mathrm{KOH}$ solution, etc. For comparison to these results, the mixture of pure chemicals of alumina and silica in the molecular ratio of kaolin $1: 2 \quad\left(\mathrm{Al}_{2} \mathrm{O}_{3}: 2 \mathrm{SiO}_{2}\right)$ was treated with alkali solution under pressure, quitely in the same conditions as above adopted, but it could not be obtained the same feldspathic product. This fact shows that alumina and silica in the calcined kaolin are not in quite free state as the mixture, but in the special combination of convenient state for the formation of alkali alumino-hydro-silicate by the hydrothermal reaction with alkali solution under pressure.

The author is now further studying on these products of alkali alumino-hydro-silicate, or artificial or synthesized feldspathic compounds, i.e., the one being $\mathrm{Na}_{2} \mathrm{O} \cdot \mathrm{Al}_{2} \mathrm{O}_{3} \cdot 2 \mathrm{SiO}_{2} \cdot \mathrm{nH}_{2} \mathrm{O}$, nephelin hydrate or carnegieite hydrate and the other being $\mathrm{K}_{2} \mathrm{O} \cdot \mathrm{Al}_{2} \mathrm{O}_{3} \cdot 2 \mathrm{SiO}_{2} \cdot \mathrm{nH}_{2} \mathrm{O}$, kali-nephelin hydrate or kaliophilite hydrate, or their base exchanging properties, their uses, etc. These results will be reported in the next paper.

(Institute of Silicate Industry, Department of Applied Chemistry, Faculty of Engineering, Imperial University of Tokio, Japan)

(1) 緒

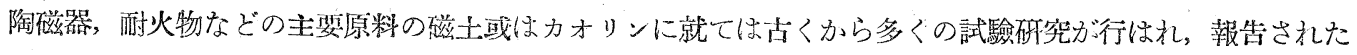
ものが枚擧に遑のない位多數めつて今更何等呼究する餘地力゙無い樣に見えるが近年又亦カオリンに就ての研究 が各方面で行はれて居ることは此のカォリン或は其の主體である珪酸攀土水和物のカオリナイトに就て從來の 研究報告或は著書 (J.Stark: Die physikalich-technische Untersuchung keramischer Kaoline, 1922) の程 度の呼究試驗方法から一步を進めて各種の科學的試驗砽究方法に依つて詳細な研究を行つて見るとカオリンの 主體の珪酸攀土水和物が單にカオリナイト $\left(\mathrm{Al}_{2} \mathrm{O}_{3} \cdot 2 \mathrm{SiO}_{2} \cdot 2 \mathrm{H}_{2} \mathrm{O}\right.$, Kaolinite $)$ だけでなく他の各種珪酸攀土水 和物 $l \mathrm{Al}_{2} \mathrm{O}_{3} \cdot m \mathrm{SiO}_{2} \cdot n \mathrm{H}_{2} \mathrm{O}$ の生成含有に依つて其の性狀に著しい差办起り, 又此の諸性狀の改變を行る得るこ となどが逍々と知れて來て居るやろである。

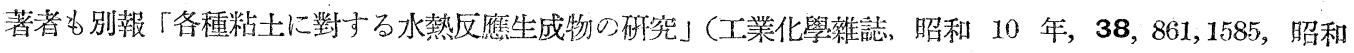
11 年, 39，6，77，183 等）中磁土にアルカリ溶液の加塺加熱の下の水熱反應生成物の試驗などに於ても此の

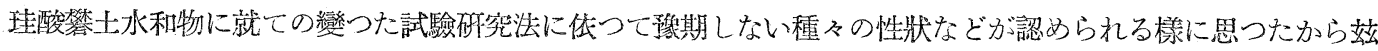
に磁土に就て種々の方面から試驗することが珪酸籃化學なり其の工檠上にも意義があることと思つて茲に各種 カォリン質試料を集妙て其の研究を初めたのであることを最䘞゙述べて置いて逐次試驗研究の結果をぽつぽつ

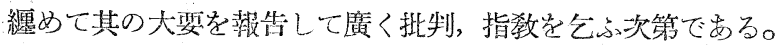

\section{（2）試驗試 料}

本報の研究試料に供したのは朝鮮厷の純カオリナイト確物 3 種とチエッコ或ッェットッッ產カオリンの水簛

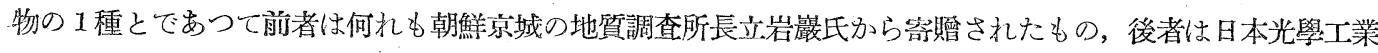

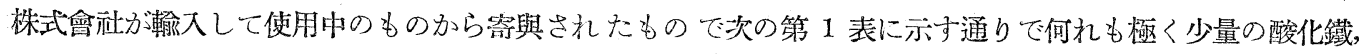
不灰，苦土，アルカリ等を含さが他の一般のカオリンから見ると非常にカオリナイト $\mathrm{Al}_{2} \mathrm{O}_{3} \cdot 2 \mathrm{SiO}_{2} \cdot 2 \mathrm{H}_{2} \mathrm{O}$ の 理論數によく近似した攀士, 珪酸, 水から成るものである。 
第 1 表 カオリナイト及び磁土試料の化學成分

\begin{tabular}{|c|c|c|c|c|c|c|c|c|}
\hline 記㩆虎 & $\begin{array}{l}\text { 試 料 名, 地各 } \\
\text { カオリナイトの理論數 }\end{array}$ & $\begin{array}{c}\text { 灼熱減量 } \\
13.96 \%\end{array}$ & $\begin{array}{c}\text { 理 酸 } \\
46.51 \%\end{array}$ & 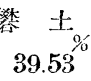 & $\begin{array}{r}\% \\
\end{array}$ & & 苦 & $100.00 \%$ \\
\hline (A) & 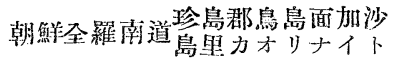 & 14.01 & 46.10 & 39.44 & 痕跡 & 0.53 & 痕跡 & 100.08 \\
\hline (B) & $\begin{array}{l}\text { 珍島郡鳥島面加士 } \\
\text { 島カオリナイト }\end{array}$ & 14.30 & 45.92 & 59.10 & 0.54 & 痕跡 & 痕跡 & 99.86 \\
\hline (C) & $\begin{array}{l}\text { 海南郡㣴山面王埋 } \\
\text { 川カオナナイ }\end{array}$ & 14.81 & 45.22 & 38.72 & 0.43 & 痕跡 & 痕跡 & 99.18 \\
\hline (D) & チエッコ或ツェットリッツ磁土 & 13.61 & 46.18 & 39.03 & 0.17 & 0.40 & 0.40 & 99.79 \\
\hline
\end{tabular}

是等の試料の中 $(\mathrm{A}),(\mathrm{B}),(\mathrm{C})$ の 3 種は其の量も少いため全く基礎的の實驗數種を行ふ試翻に供したばかりで

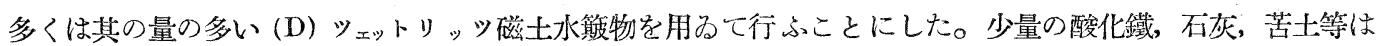
殆んど影響がないものと見て差支へないものである。是等の試料を用るて行つた實驗結果は第 4 節以下に逐次 揭げることにしやう。

\section{(3) カオリナイト，磁土に關する文献}

最初にも述べた樣に磁土，カオリナイトに就て試驗㗑究し報告されたものは全く枚舉に遑がなく是等を詳細 に揭げることは至難のことであるのは云ふ汽もない。唯茲には本報の砾究に稍深い威係があるものばかりに就 て次の樣に數個の交献を紹介して置くことにし，本報の試驗䟲究が淮むにつれて其の都度關係の深い交献は各 々の場合に到つてから適宜引照することにしたい。

先づカオリナイト，磁土の熱的性質に就ての文獻はスタルク氏の著竖 (J. S:ark: Die Physikalisch-Technische Untersuchung Keramischer Kaoline, 1922)，サール氏著罾（A. B. Searle: The Chemistry and Physics and other Ceramic Materials, 1933) 等を初め多くの黨業書及び砤究試驗報告に見られるから玆に 詳論する必要もない。其の要點を摘錄したものは拙著「耐火物の化學と試驗法」(炤和 11 年版，9１6）の通 りである。是等種々の文獻研究報告の主要點を摘銑して見ると（1）カオリナイトは 500 カ $600^{\circ} \mathrm{C}$ で其の化合水 2 分子兮殆んど發散してしまふ，(2)後に殘る攀士と珪酸とはメタカオリン Meta-kaolin とも秲して居る,(3) 此の攀土と珪酸とは其の結合が緩くなつて攀土は酸䧹に, 珪酸はアルカリ液に溶解, 抽出され易くなる, (4)此 の攀土なり珪酸なりが酸又はアルカリ液への溶解，抽出は約 800 ～ $900^{\circ} \mathrm{C}$ で最大となり之を越し高溫になると 少くなる，(5) $900^{\circ} \mathrm{C}$ 以上で攀士と琟酸とが 1 分子宛結合してシリマナイト Sillimanite $\mathrm{Al}_{2} \mathrm{O}_{3} ・ \mathrm{SiO}_{2}$ 㚙出來，

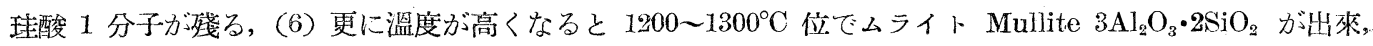
珪酸の遊離のものはクリストバライト，Cristoballite, $\mathrm{SiO}_{2}$ になる，(7) 更に溫度が高くなると SK 34〜35， 1750 $1770^{\circ} \mathrm{C}$ で全體が熔融して來る，此の中には $\mathrm{Al}_{2} \mathrm{O}_{3} \cdot 2 \mathrm{SiO}_{2}, \mathrm{Al}_{2} \mathrm{O}_{3} \cdot \mathrm{SiO}_{2}, 3 \mathrm{Al}_{2} \mathrm{O}_{3} \cdot 2 \mathrm{SiO}_{2}, \mathrm{SiO}_{2}$ などが共熔 して居るものであらふっ

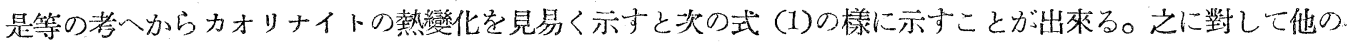

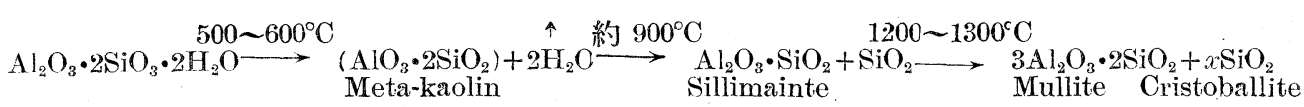

$$
\left\{\begin{array}{l}
\mathrm{Al}_{2} \mathrm{O}_{3} \cdots \text { 酸に可溶 } \\
\mathrm{SiO}_{2} \cdots \text { アルカリに可溶 }
\end{array}\right.
$$


示し方をして居るものには最近ブドニコフ氏 (P. P. Budnikoff, Ber. der Deut. Ker. Ges., 1935, 16, 349) は次の式 (2)の樣に此のカオリンの熱變化に於て㸴究した結果を示した。

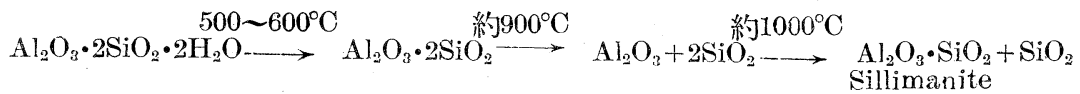

$$
\begin{aligned}
& 1200 \sim 1300^{\circ} \mathrm{C} \\
& \longrightarrow \quad 3 \mathrm{Al}_{2} \mathrm{O}_{3} \cdot 2 \mathrm{SiO}_{2}
\end{aligned}
$$

更に稍古いがヒスロプ氏 (J. Hyslop, Transact. Cer. Soc., 1924, 24) は次の式（3)の樣に示しカオリナイト が $500 \sim 600^{\circ} \mathrm{C}$ から $800 \sim 900^{\circ} \mathrm{C}$ の間の溫度で化合水が取れて攀土と珪酸とが緩かな結合になつて䙪土が酸

$$
4\left(\mathrm{Al}_{2} \mathrm{O}_{3} \cdot 2 \mathrm{SiO}_{2} \cdot 2 \mathrm{H}_{2} \mathrm{O}\right) \stackrel{\text { 約 } 550^{\circ} \mathrm{C}}{\longrightarrow} 4 \mathrm{Al}_{2} \mathrm{O}_{3} \cdot 3 \mathrm{SiO}_{2}+5 \mathrm{SiO}_{2}+8 \mathrm{H}_{2} \mathrm{O} \stackrel{\text { 約 } 850^{\circ} \mathrm{C}}{\longrightarrow} \underset{\text { Sillimanite }}{\left(\mathrm{Al}_{2} \mathrm{O}_{3} \cdot \mathrm{SiO}_{2}\right)+y \mathrm{Al}_{2} \mathrm{O}_{3}+x \mathrm{SiO}_{2}}
$$

約 $1060^{\circ} \mathrm{C}$

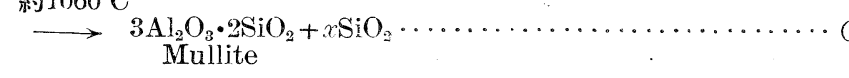

に，珪酸がアルカリに溶出し易いことを示すのに式 (1)の樣に $\left(\mathrm{Al}_{2} \mathrm{O}_{3} \cdot 2 \mathrm{SiO}_{2}\right)$ 又は Meta-kaolin として示す のと式 (2)の樣に $\mathrm{AlO}_{3}$ ・ $\mathrm{SiO}_{2}$ 加 $\mathrm{Al}_{2} \mathrm{O}_{3}+2 \mathrm{SiO}_{2}$ として示寸のと式 (3)の樣に $4 \mathrm{Al}_{2} \mathrm{O}_{3} \cdot 3 \mathrm{SiO}_{2}$ の樣なものを設 けるのとある。

是等の熱變化を化學的に比較試驗し夫等を基礎に於てカオリナイトの諸性質の試驗政究に入ることにし本報 では先づ前節に示したッェッリッッ磁土が其の量も多く且つ化學成分が充分本研究の目的に沿ふ純粹度のもの であるので專ら此の磁土を用るることにし他は少量の試料で足りる試驗に供用した。次節以下に其の試驗結果 の大要变さう。

\section{（4）各温度の磁土渥燒物の戀化}

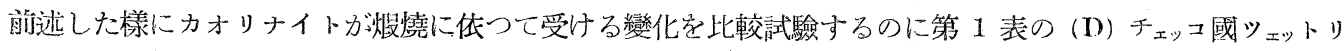
ッツ磁士に就て次の樣に比較試驗した。郎ち煆燈溫度は $400^{\circ} \mathrm{C}$ 以上, $1500^{\circ} \mathrm{C}$ 迄の各溫度に 1 時問乃至 4 特 間熱したものに就て（1 煆燒に依る減量，（2）烺燒物を $10 \% \mathrm{NaOH}$ 溶液と次に $5 \% \mathrm{HCl}$ 溶液に依る可溶分 析法を適用して (a) 不溶部分と, (b) 可溶部分の珪酸, 䙪士, 酸化鐵, 石灰, 苦士等を定量し, (3) 煆燒減量 郎ち發散した結合水と可溶攀土との分子比，(4) 可溶攀土と可溶珠酸との分子比，(5) 比重等の各項目に就て 詳細に比較試驗した結果は次の第 2 表の通りである。

郎ち此の結果で見えるゃらに $850^{\circ} \mathrm{C}$ 榐燒物が可溶攀土は最も多く不溶部分が最も少いもので, 其の前後 $800^{\circ} \mathrm{C} \sim 900^{\circ} \mathrm{C}$ 煆燒物になるにつれて不溶部分の量が多く, 可溶攀土が減少して來て, 偷一方に $400^{\circ} \mathrm{C}$ 加熱物, 他方 $1100 \sim 1260^{\circ} \mathrm{C}$ 加熱物以上 $1300 \sim 1500^{\circ} \mathrm{C}$ 加熱物になるにつれて急に不溶部分は增大し又可溶攀士も急に 減少して來ることがよく知れる。可溶珪酸の量は $550^{\circ} \mathrm{C}$ から次第に霄加し $1100^{\circ} \mathrm{C}$ 加熱物で最多となり次第に 減少して來て遊離珄酸が Tridymite, Cristoballite となり他は $\mathrm{Al}_{2} \mathrm{O}_{3} \cdot \mathrm{SiO}_{2}$ の Sillimanite 又は $3 \mathrm{Al}_{2} \mathrm{O}_{3} \cdot 2 \mathrm{SiO}_{2}$ の Mullite となつて可溶攀土が急に減少することが知れる。佾 $550 \sim 900^{\circ} \mathrm{C}$ 迄の $\mathrm{A}_{2} \mathrm{O}_{3} / \mathrm{H}_{2} \mathrm{O}, \mathrm{Al}_{2} \mathrm{O}_{3} / \mathrm{SiO}_{2}$ の 分子比は $0.43 \sim 0.45,0.53 \sim 0.58$ となつて殆んど 0.5 の數值を取ることはカオリナイト $\mathrm{Al}_{2} \mathrm{O}_{3} \cdot 2 \mathrm{SiO}_{2} \cdot 2 \mathrm{H}_{2} \mathrm{O}$

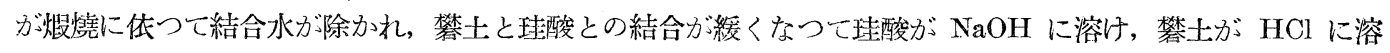
け而も $\mathrm{Al}_{2} \mathrm{O}_{3} / \mathrm{H}_{2} \mathrm{O}$ が 1:2, $\mathrm{Al}_{2} \mathrm{O}_{3} / \mathrm{SiO}_{2}$ が $1: 2$ の分子比の 0.5 に近い數值を取ることを示して属るものであ 
第 2 表＼cjkstart各溫度の椵燒磁土の性狀比較試驗表

\begin{tabular}{|c|c|c|c|c|c|c|c|c|c|c|c|c|}
\hline \multirow{2}{*}{\multicolumn{2}{|c|}{$\underbrace{\text { 烺燒條作 }}$}} & \multicolumn{7}{|c|}{ 煆燒物に湮する } & \multirow{3}{*}{$\begin{array}{l}\text { 煆 燒 } \\
\text { 減 量 }\end{array}$} & \multirow{3}{*}{ 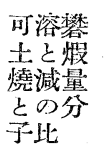 } & \multirow{3}{*}{$\begin{array}{l}\text { 可溶䙪 } \\
\text { 土之叮 } \\
\text { 溶理酸 } \\
\text { と分 } \\
\text { 子比 }\end{array}$} & \multirow{3}{*}{$\begin{array}{l}\text { 煆燒物 } \\
\text { の比重 }\end{array}$} \\
\hline & & \multirow{2}{*}{$\begin{array}{l}\text { 不 溶 } \\
\text { 部 分 }\end{array}$} & \multicolumn{6}{|c|}{ 可溶部分 } & & & & \\
\hline 溫 度 & 時間 & & 珄·酸 & \pm & 酸化鐵 & 石 & 灰 & 合 䛨 & & & & \\
\hline${ }^{\circ} \mathrm{C}$ & & $\%$ & $\%$ & $\%$ & $\%$ & & $\%$ & & $\%$ & $\%$ & $\%$ & \\
\hline 400 & 2 & 71.86 & 9.58 & 6.99 & 0.43 & & 0.36 & 17.36 & 1.74 & 0.70 & 0.43 & 2.623 \\
\hline 550 & 2 & 19.64 & 38.09 & 35.48 & 0.68 & & 0.35 & 74.60 & 12.57 & 0.44 & 0.55 & \\
\hline 800 & 4 & 17.20 & 40.96 & 38.28 & 0.73 & & 0.34 & 80.31 & 13.43 & 0.44 & 0.55 & \\
\hline 850 & 4 & 12.10 & 44.74 & 40.00 & 0.98 & & 0.39 & 86.11 & 13.53 & 0.45 & 0.53 & \\
\hline $9 \subset 0$ & 2 & 13.43 & 43.15 & 39.41 & 0.98 & & 0.93 & 84.47 & 13.70 & 0.44 & 0.54 & 2.685 \\
\hline 900 & 4 & 18.55 & 39.13 & 38.66 & 0.78 & & 0.67 & 79.24 & 13.79 & 0.43 & 0.58 & \\
\hline 1100 & 2 & 29.63 & 51.82 & 18.92 & 0.78 & & 0.69 & 72.21 & 13.74 & 0.21 & 0.22 & 2.693 \\
\hline 1260 & 2 & 53.38 & 40.88 & 4.74 & 0.74 & & 0.52 & 46.88 & 14.00 & 0.05 & 0.07 & $\longrightarrow$ \\
\hline 1300 & 1 & 62.21 & 33.98 & 4.02 & 0.55 & & 0.66 & 39.21 & 14.45 & 0.04 & 0.07 & 2.689 \\
\hline 1400 & 1 & 9.73 .45 & 24.30 & 3.21 & 0.44 & & 0.65 & 28.60 & 14.72 & 0.03 & 0.08 & 2.678 \\
\hline 1500 & 1 & 76.37 & 22.85 & 2.30 & 0.52 & & 0.60 & 26.27 & 15.03 & 0.02 & 0.06 & 2681 \\
\hline
\end{tabular}

る。是等の變化は略前揭の式 (1)，(2)，(3) に示して居る事實を示すすのと見ることが出來る。比重の變化を 見ると此の磁土の生のすのの此重 2.568 が $4.00^{\circ} \mathrm{C}$ 以上各溫度に蝦燒したものの比重は 2.62 から 2.69 迄次第 に昇上が見られるが急な變化は 400 5 $50^{\circ} \mathrm{C}$ 附近の炕熱減量が急に多くなつてメタカオリンになるところて其 の後の高い加熱です餘り大きい變化はなく徐ふに大きくなつて居る。

\section{（5）磁土煆燒物のプルカリ液に依る加壓水熱反礁の生成物}

前箍の $550 \sim 900^{\circ} \mathrm{C}$ 㩔燒磁士はカオリナイトの結合水が除かれメタカオリンの攀土と珪酸とが酸, アルカリ に溶出し易く結合の緩いものになつたことを明らかにした。炏に斯樣に攀土と珄酸との結合の緩んだメタカ才 リンに就て $\mathrm{NaOH}$ 又は $\mathrm{KOH}$ のアルカリ液に依る加壓水熱式處理を行へばどんな變化を受けるが比較試 驗して見た。其の方法は別報「各種粘土に對する水熱反應生成物の㸴究」(第 1 第 5 報)(工業化學雜誌，昭 和 10 年, 38, 861，1585；昭和 11 年，39，6，77，183）に揭蛓して居ると同樣に試料の粉未を $15 \sim 30 \%$ の $\mathrm{NaOH}, \mathrm{KOH}$ などのアルカリ溶液と共にォートクレーブ中で $10 \sim 20$ 氯壓, 約 $180 \sim 210^{\circ} \mathrm{C}$ に 1 時間水蒸氣筀 の下に加熱作用させた後直ちに滤過し水で充分洗熦した後 $105 \sim 110^{\circ} \mathrm{C}$ に乾燥した殘滓の量を測定し生成物の 量を知り, 濾液の方に溶出した理酸, 攀土以下の諸成分の量を定量した。此の方法を上述のメタカオリン郎ち磁 土烺燒物に適用した場合には前節のメタカオリンを $10 \% \mathrm{NaOH} て ゙$ 常壓の下に約 $100^{\circ} \mathrm{C}$ に加熱すると珪酸が 38〜 44\% も溶解したのでめつたが此の加壓加熱の場合には溶解する珪酸は少く大部分不溶殘渣の方に大つた ことは著しい差異である。次に此の殘渣を箵酸 (1:2) 液次いで炭酸曹達液で處理すると殆んど完全に溶解して 不溶部分が少く, 灼熱減量 (大部分結合水), アルカリ, 攀土及び珠酸の可溶部分などから $\mathrm{Na}_{2} \mathrm{O} \cdot \mathrm{Al}_{2} \mathrm{O}_{3} \cdot 2 \mathrm{SiO}_{2}$ ・ $\mathrm{nH}_{2} \mathrm{O}, \mathrm{K}_{2} \mathrm{O} \cdot \mathrm{Al}_{2} \mathrm{O}_{3} \cdot 2 \mathrm{SiO}_{2} \cdot \mathrm{nH}_{2} \mathrm{O}$ が生成することは次の第 3 表に示寸やうに確認寸ることが出來た。 
第 3 表 磁土烺燒物のアルカリ液に依る加㿄水熱處理生成物

\begin{tabular}{|c|c|c|c|c|c|c|c|c|c|c|c|c|}
\hline \multicolumn{3}{|c|}{ 脚燒條作 } & \multicolumn{4}{|c|}{ 試料,アルカリ液㑛用量 } & \multicolumn{3}{|c|}{ 加嬮加熱條作 } & \multicolumn{3}{|c|}{ ホートクレーブ處理生成物 } \\
\hline & & 䙺 罋 & & & ルカリ & & & & & 不 溶 & 溶獬 & 成分 \\
\hline 溫 菖 & 時間 & 減 量 & 試料 & 種 别 & 濃 度 & 容量 & 壓 力 & 溫 度 & 時 間 & 生成物 & 珪 酸 & $\begin{array}{l}\text { 攀土: Z } \\
\text { 酸化鐵 }\end{array}$ \\
\hline 生 & の 磁 & 土\% & $\begin{array}{l}\mathrm{g} \\
3\end{array}$ & $\mathrm{NaOH}$ & $\begin{array}{l}\% \\
30\end{array}$ & $\begin{array}{r}\text { cc } \\
20\end{array}$ & $\begin{array}{l}\text { 筑厴 } \\
20\end{array}$ & $\begin{array}{r}{ }^{\circ} \mathrm{C} \\
210\end{array}$ & $\begin{array}{l}\text { 時闃 } \\
1\end{array}$ & $\begin{array}{r}\% \\
118.3\end{array}$ & 2.44 & $\begin{array}{r}\% \\
1.05\end{array}$ \\
\hline 500 & $1.5^{\text {nat }}$ & $9.92^{\%}$ & 3 & $\mathrm{NaOH}$ & 30 & 20 & 20 & 210 & 1 & 120.9 & 2.90 & 1.05 \\
\hline 900 & 2 & 13.64 & 3 & $\mathrm{NaOH}$ & 30 & 20 & 20 & 210 & 1 & 136.5 & 3.31 & 1.32 \\
\hline 1100 & 2 & 13.74 & 3 & $\mathrm{NaOH}$ & 30 & 20 & 20 & $210^{\circ}$ & 1 & 134.4 & 2.65 & 1.88 \\
\hline 1260 & 2 & 14.00 & 3 & $\mathrm{NaOH}$ & 30 & 20 & 20 & 210 & .1 & 134.1 & 2.88 & 1.89 \\
\hline 生 & の 磁 & \pm & 3 & $\mathrm{KOH}$ & 30 & 20 & 20 & 210 & 1 & 101.9 & 0.56 & 3.28 \\
\hline 500 & 2 & 8.44 & 3 & $\mathrm{KOH}$ & 30 & 20 & 20 & 210 & 1 & 126.8 & 1.21 & 0.89 \\
\hline 900 & 2 & 13.65 & 3 & $\mathrm{KOH}$ & 30 & 20 & 20 & 210 & 1 & 135.7 & 2.17 & 0.24 \\
\hline
\end{tabular}

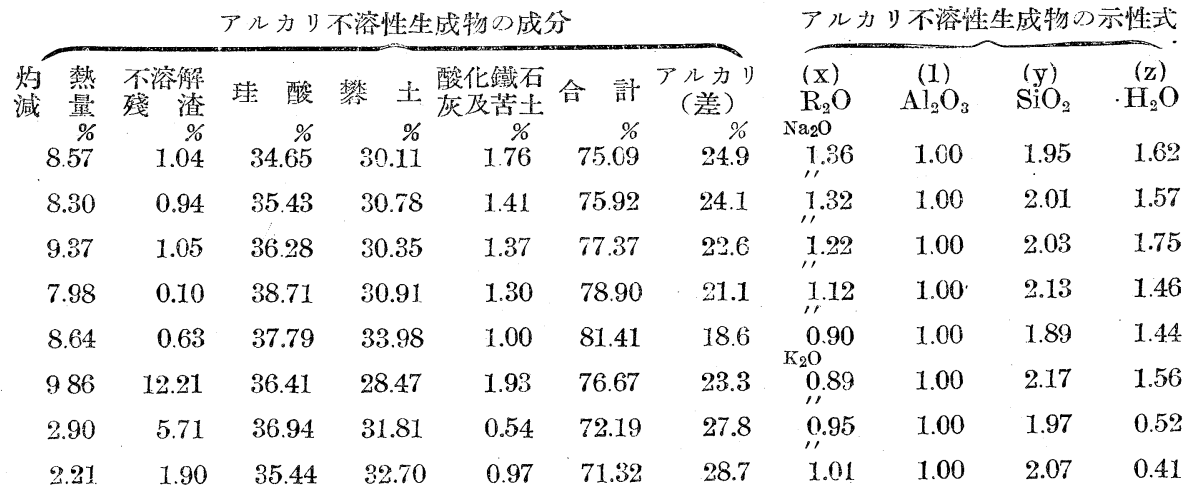

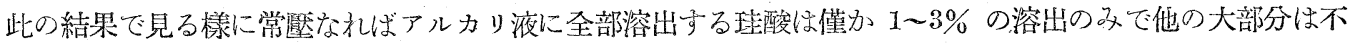

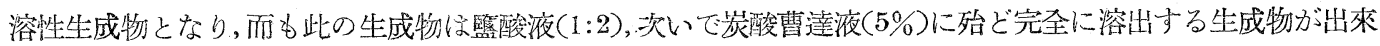
る事は別報「各種粘土に對する水熱反應生成物の研究」に於て生のカオリンに就て $\mathrm{NaOH}, \mathrm{KOH}$ の 15 30\% 溶 液で上表と全く同一條件で行つたものと全く同樣の生成物を生じ而も此の生成物中の主成分のアルカリ $\left(\mathrm{R}_{2} \mathrm{O}\right)$, 攀土 $\left(\mathrm{Al}_{2} \mathrm{O}_{3}\right.$ ) 珠酸 $\left(\mathrm{SiO}_{2}\right)$, 化合水 (炕熱減量を以つてして居るので稍不正確, $\left.\mathrm{H}_{2} \mathrm{O}\right)$ ) 分子比を求めて見たもの も殆んど同樣な結果を得て居る點から考へて見ても磁土を 500 $900^{\circ} \mathrm{C}$ に瑕燒して其の化合水を失つて攀土と 珪酸との結合が緩くなつたメタカオリンも之をアルカリ溶液と加壓水熱處理を行へば生のカリリンと同㮏のア ルカリ攀土珪酸譼水和物 $\mathrm{R}_{2} \mathrm{O} \cdot \mathrm{Al}_{2} \mathrm{O}_{3} \cdot 2 \mathrm{SiO}_{2} \cdot \mathrm{nH}_{2} \mathrm{O}$ を生ずることを確め得たのは此のメタカオリン中の結合が 緩くなつ2゙ンタカオリンの攀土と珪酸とが單に混じて居るに過ぎないと見る前揭式 $(2)$ ブドニュフ氏の見方が 正しいか，或は緩くとも特殊の結合にあると見る式(1)の $\left(\mathrm{Al}_{2} \mathrm{O}_{3} \cdot 2 \mathrm{SiO}_{2}\right)$ とする見方が正しいか等を決定する䳡 の參考にしたい。少 $\mathrm{KOHを}$ 用るたものが $105 \sim 110^{\circ} \mathrm{C}$ の乾懆で既に生成物の結合水が 0.5 分子位に少いるのに なつて居ることはNaOH を用るた時の約1.5分子(之は灼熱減量全部を結合水と見做し直接定量したものでない から少し多くなつて居て別報の多くの場合の樣に 1.0 分子とすべきか今のところ未定)の樣に多いのとは變つ て居る默で此の點は多くの實驗て認めて居り目下詳細に研究試驗中で次の節以下にも其の 1 部を報告しやう。

\section{（6）拄酸，礬土，酸化鐵の配合物の加壓水熱處理試驗}


前節の磁土楖燒物で攀土と珪酸との結合が㗔くなつたメタカオリンを $\mathrm{KOH}$ 又は $\mathrm{NaOH}$ 溶液で加壓水熱 處理をすれば磁土同樣 $\mathrm{R}_{2} \mathrm{O} \cdot \mathrm{Al}_{2} \mathrm{O}_{3} \cdot 2 \mathrm{SiO}_{2} \cdot \mathrm{nH}_{2} \mathrm{O}$ ガ生成することを認めたので茲には全く單獨な酸化物の攀土 と珪酸との配合物に就て同樣の生成物が出來るかどうかを試驗することにし同時に攀士 $\mathrm{Al}_{2} \mathrm{O}_{3}$ の外水酸化ア ルミニウム $\mathrm{Al}_{2}(\mathrm{OH})_{6}$ をも用る, 更に攀士, 其の水酸化物の代りに酸化鐵 $\mathrm{Fe}_{2} \mathrm{O}_{3}$, 其の水酸化鐵 $\mathrm{Fe}_{2}(\mathrm{OH})_{6}$ を用 る，之を珠酸と配合したものに就ても同樣に $\mathrm{NaOH}$ 溶液 (30\%) を用るて前節と同樣に加厴水熱處理を行つ た試驗結果は次の通りである。

第 4 表 攀土, 酸化鐵と珪酸との配合物に依る加壓水熱反應生成物の試驗結果

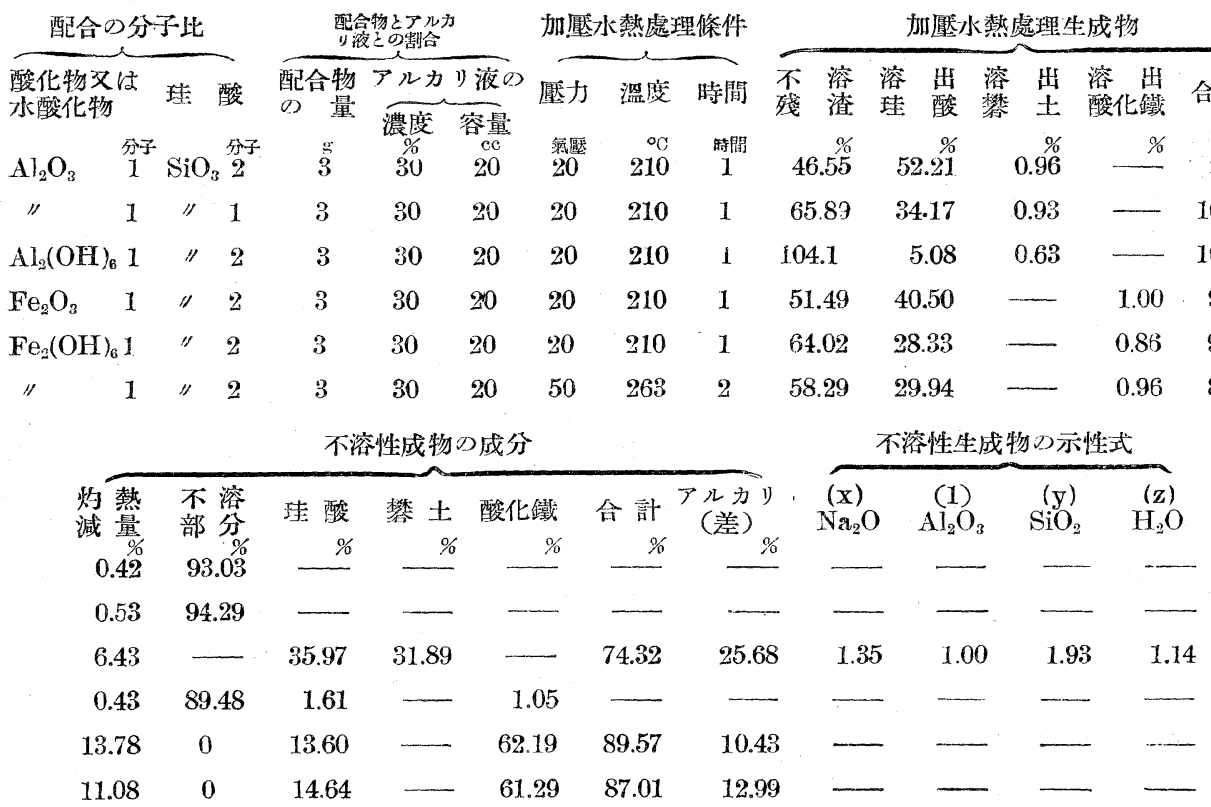

郎ち此の結果で見るやうに純藥品を用るた是等の各種配合物に依る $\mathrm{NaOH}$ 溶液中の加厧水熱處理に依つた 攀土又は酸化鐵と珪酸との配合物の場合には珪酸は殆んど全部溶出して珠酸曹達となり，攀土及び酸化鐵は不

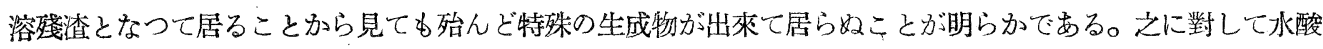
化アルミニウムを攀土に換えて用るた配合物からは明らかにアルカリに不溶性生成物が此の配合物以上の量に 出來, 之は $\mathrm{NaOH}$ 溶液には溶けないが $\mathrm{HCl}(1: 2)$ 溶液, 次いで $\mathrm{Na}_{2} \mathrm{CO}_{3}(5 \%)$ 溶液て處理すると完全に溶 将んど攀土と珪酸, 之にアルカリ $\left(\mathrm{Na}_{2} \mathrm{O}\right)$, 灼熱減量の結合水 $\left(\mathrm{H}_{2} \mathrm{O}\right)$ とから成つて居て其の示性式は前節迄 の多くの場合に得られたものと同樣に $\mathrm{Na}_{2} \mathrm{O} \cdot \mathrm{Al}_{2} \mathrm{O} \cdot 2 \mathrm{SiO}_{2} \cdot \mathrm{H}_{2} \mathrm{O}$ を生じて居ることが明らかとなつた。從つて 水酸化アルミニウムと珪酸との配合加ら出來るが禁士と珠酸との配合からは 20 氣厴, $210^{\circ} \mathrm{C}, 1$ 時間の $30 \%$ $\mathrm{NaOH}$ 溶液に体る加壓水熱處理では生成しないことは前節のヌタカオリンの場合には同一條件で出來るのと 比較して全く異る點で非常な高溫高壓の加壓水熱處理では出來るか知れないが上記の樣な同一條件では出來 るものと出來欧のとが出來ることはどうしてもメタカオリンの中の攀土と珪酸とが單なる混合物とは異うて 攀土が緩くはあるが珠酸と特殊の結合にあるものの樣に考へられるから上揭式 (1)の $\left(\mathrm{Al}_{2} \mathrm{O}_{3} \cdot 2 \mathrm{SiO}_{2}\right)$ として示 したのである。是等の點は後日更に試驗を重ねたい。

次に酸化鐵と珪酸とアルカリとの 3 成分間に出來る自然の礦物で本報に關倸のあるものはカオリナイト 
$\mathrm{Al}_{2} \mathrm{O}_{3} \cdot 2 \mathrm{SiO}_{2} \cdot 2 \mathrm{H}_{2} \mathrm{O}$ の攀土が酸化鐵で置き換光られた $\mathrm{Fe}_{2} \mathrm{O}_{3} \cdot 2 \mathrm{SiO}_{2} \cdot 2 \mathrm{H}_{2} \mathrm{O}$ 又は $\mathrm{H}_{2} \mathrm{Fe}_{2} \mathrm{Si}_{2} \mathrm{O}_{8} \cdot \mathrm{H}_{2} \mathrm{O}$ の式を持つ たノントロナイト Nontronite がある(C. Bischof, Die Feuerfesten Tone, 23)。倘此のノントロナイトの合成 に就て研究したものには最近エウェル氏等 (R. H. Ewell and H. Insley, Bur. Standard Journal Research, 1935, 15, (2), 173; Bur. Standard T. N. B., 1935，(220)，82）がある。之では水酸化鐵り水酸化珪素の混合ろ゙ ルを 310 - $390^{\circ} \mathrm{C}$ の高壓水熱式合成に依つて得たもので水酸化アムミニウムと水酸化珪素々の混合ゲルからカ オリナイト,ディカイト,ナクライト,バイデライト(Kaolinite, Dickite Nacrite, Beidellite) 等を合成し たと同樣にして得たものである。上揭の試驗は之とは異るが此のノントロナイトの樣に $\mathrm{Fe}_{2} \mathrm{O}_{3} \cdot 2 \mathrm{SiO}_{2} \cdot 2 \mathrm{H}_{2} \mathrm{O}$ が天然にあり, 又合成される以上はやはり此のノントロナイト $\mathrm{Fe}_{2} \mathrm{O}_{3} \cdot 2 \mathrm{SiO}_{2} \cdot 2 \mathrm{H}_{2} \mathrm{O}$ の 1 分子の結合水がアル カリで置換されたものも同樣に合成される䈏であるから水酸化アルミニウムと珪酸との $1: 2$ 配合物からアル カリ液に依る加壓水熱處理で $\mathrm{Na}_{2} \mathrm{O} \cdot \mathrm{Al}_{2} \mathrm{O}_{3} \cdot 2 \mathrm{SiO}_{2} \cdot \mathrm{nH}_{2} \mathrm{O}$ を得を樣に水酸化鐵と珪酸との配合物を $\mathrm{NaOH}$ 溶液 で 20 氣壓 (約 $210^{\circ} \mathrm{C}$ ) と 50 氣壓（約 $263^{\circ} \mathrm{C）} \mathrm{との} 2$ 條件の下に行つて見たのであるが上揭の表で見る通り 酸化鐵と珪酸との $1: 2$ 配合物郎ち $\mathrm{Fe}_{2} \mathrm{O}_{3}: 2 \mathrm{SiO}_{2}$ 配合物では殆んど變化を受けないで酸化鐵は不溶解殘渣に, 珪酸はアルカリ液に溶出して居るのに對し水酸化鐵と珪酸との $1: 2$ 配合物郎ち $\mathrm{Fe}_{2}(\mathrm{OH})_{6}: 2 \mathrm{SiO}_{2}$ 配合物では 20 氣壓の低い壓力, $210^{\circ} \mathrm{C}$ の低い溫度，1 時間の短い加熱では約 $10 \sim 20 \%$ だけ生成して居ることは不溶殘椬 が多くなり，其の不溶性生成物の中に珪酸分があることなどからよく知れるが此の不溶殘渣中には水酸化鐵も 相當にあるので $\mathrm{Na}_{2} \mathrm{O} \cdot \mathrm{Fe}_{2} \mathrm{O}_{3} \cdot 2 \mathrm{SiO}_{2} \cdot \mathrm{nH}_{2} \mathrm{O}$ と $\mathrm{Fe}_{2}(\mathrm{OH})_{6}$ との混合物であるから是等を分けなれば明確な

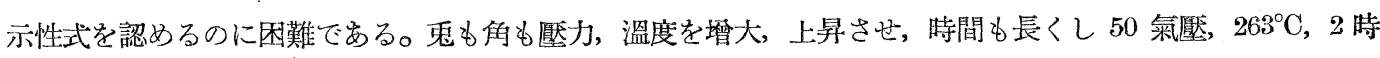

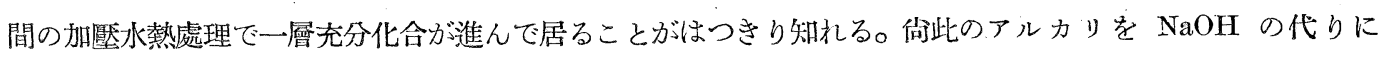
$\mathrm{KOH}$ を用るると $\mathrm{K}_{2} \mathrm{O} \cdot \mathrm{Fe}_{2} \mathrm{O}_{3} \cdot 2 \mathrm{SiO}_{2} \cdot \mathrm{nH}_{2} \mathrm{O}$ が出來 $\mathrm{Fe}_{2}(\mathrm{OH})_{6}, \mathrm{SiO}_{2}$ の化合しないるのが全部 $\mathrm{KOH} に$ に溶け るからアルカリ不溶殘渣は $\mathrm{K}_{2} \mathrm{O} \cdot \mathrm{Fe}_{2} \mathrm{O}_{3} \cdot 2 \mathrm{SiO}_{2} \cdot \mathrm{nH}_{2} \mathrm{O}$ だけになつて其の示性式を決定するのには便利であるか ら是等の點は更に次報に詳しい研究結果を示さう。

\section{（7）カオリナイトよりのアルカリ攀土珪酸䜿水和物 $\mathrm{R}_{2} \mathrm{O} \cdot \mathrm{Al}_{2} \mathrm{O}_{3} \cdot 2 \mathrm{SiO}_{2} \cdot \mathrm{nH}_{2} \mathrm{O}$ 生成の文献就て}

上述及び別報（「各種佔土に對する水熱反應生成物の砢究」，第 $1 \sim 5$ 報，工業化學雜誌，昭和 10 年, 38, $861 ， 1585 ;$ 昭和 11 年, 39，6，77，183） で屢々得て居るカオリナイト $\mathrm{Al}_{2} \mathrm{O}_{3} \cdot 2 \mathrm{SiO}_{2} \cdot 2 \mathrm{H}_{2} \mathrm{O}$ のアルカリ液に 依る水熱式處埋生成物 $\mathrm{R}_{2} \mathrm{O} \cdot \mathrm{Al}_{2} \mathrm{O}_{3} \cdot 2 \mathrm{SiO}_{2} \cdot \mathrm{nH}_{2} \mathrm{O}$ が得られること, 其の給合水は生成物を $105-110^{\circ} \mathrm{C}$ に乾燥し たものでは $\mathrm{NaOH}$ 使用のときは $\mathrm{Na}_{2} \mathrm{O} \cdot \mathrm{Al}_{2} \mathrm{O}_{3} \cdot 2 \mathrm{SiO}_{2} \cdot \mathrm{nH}_{2} \mathrm{O}$ の $\mathrm{n}$ が㸛 1.0 位から $1.3 \sim 15$ 郎ち 1 分子の $\mathrm{Na}_{2} \mathrm{O} \cdot \mathrm{Al}_{2} \mathrm{O}_{3} \cdot 2 \mathrm{SiO}_{2} \cdot \mathrm{H}_{2} \mathrm{O}$ に相當するものから時々は稍多くて 1.3 - 1.5 分子位の數值を得たが之は多分附着水 が幾分取れないで踐つて居るからであらであらうと思つて此の默は後日決定することにした。又 KOHを用る るときは $\mathrm{K}_{2} \mathrm{O} \cdot \mathrm{Al}_{2} \mathrm{O}_{3} \cdot 2 \mathrm{SiO}_{2} \cdot \mathrm{nH}_{2} \mathrm{O}$ の $\mathrm{n}$ が非常に小さく $0.2 \sim 0.4$, 時には 0.5 位郎ち給合水が取れ易く $50^{\circ} \mathrm{C}$ 乾燥でも取れてしまふことを認め此の點は目下研究中で $\mathrm{Na}_{2} \mathrm{O} \cdot \mathrm{Al}_{2} \mathrm{O}_{3} \cdot 2 \mathrm{SiO}_{2} \cdot \mathrm{nH}_{2} \mathrm{O}$ の場合よりは遥かに少い

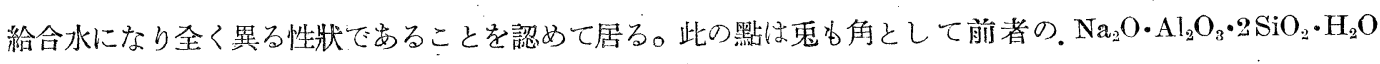
に就ての從來の文献を見るとチェグット氏 (St. Thugutt, Zeitschrift f. anorg. Chem., 1891，2，64；N. Jahrb. f. Min., 1894, 9, 554) 及びレンベルグ氏 (J. Lemberg, Zeitschrift d. Deut. Geol. Ges., 1887, 39, 562) などがカオリンから得たものを $4\left\{\mathrm{Na}_{2} \mathrm{O} \cdot \mathrm{Al}_{2} \mathrm{O}_{3} \cdot 2 \mathrm{SiO}_{2}\right\} \cdot 5 \mathrm{H}_{2} \mathrm{O}$ 又は $\mathrm{Na}_{2} \mathrm{O} \cdot \mathrm{Al}_{2} \mathrm{O}_{3} \cdot 2 \mathrm{SiO}_{2} \cdot 1.25 \mathrm{H}_{2} \mathrm{O}$ として 
示し之を高溫度に溫めると給合水が取れて $\mathrm{Na}_{2} \mathrm{O} \cdot \mathrm{Al}_{2} \mathrm{O}_{3} \cdot 2 \mathrm{SiO}_{2}$ (カーネギート，Carnegieit，ネフェリン Nephelin，又は曹達ア!ーサイト Natron-Anorthit として灰長石, アノーサイト, $\mathrm{CaO} \cdot \mathrm{Al}_{2} \mathrm{O}_{3} \cdot 2 \mathrm{SiO}_{2}$ の石灰が 曹澾で置換されたものと稱して居る)になることを示して居る。因夕に $\mathrm{K}_{2} \mathrm{O} ・ \mathrm{Al}_{2} \mathrm{O}_{3} \cdot 2 \mathrm{SiO}_{2}$ は加里ネフェリン (Kalinephelin)，カリオフィリット(Kaliophilit)，ファセリット(Phacelit) などとも稱する。更にブカル氏 (W. Pukall, Ber. d. Deut. Chem. Ges., 1910, 2103) は磁土と $\mathrm{NaOH}$ とから得て其の式を $\mathrm{Na}_{2} \mathrm{O} \cdot \mathrm{Al}_{2} \mathrm{O}_{3}$ ・ $2 \mathrm{SiO}_{3} \cdot 2 \mathrm{H}_{2} \mathrm{O}$ とし之を稀䜿酸及びアムモニアで處理して曹達を除いて $\mathrm{Al}_{2} \mathrm{O}_{3} \cdot 2 \mathrm{SiO}_{2} ・ 3 \mathrm{H}_{2} \mathrm{O}$ を得之をカオリン酸 (Kaolinsäure 又はアルミノ珪酸, Aluminokieselsäure) と秧し上記のものは其の曹達朢として居る。最後にヴ エルナドスキー氏 (W. Vernadsky, Zeitschrift f. Krist., 34，42，63；53，273) はカオリンを雲母酸又はグ リンマー酸 (Glimmersäure) の水和物 $\mathrm{H}_{2} \mathrm{Al}_{2} \mathrm{Si}_{2} \mathrm{O}_{8} \cdot \mathrm{H}_{2} \mathrm{O}$ 又は $\mathrm{H}_{2} \mathrm{O} \cdot \mathrm{Al}_{2} \mathrm{O}_{3} \cdot 2 \mathrm{SiO}_{2} \cdot \mathrm{H}_{2} \mathrm{O}$ として示し此のグリン

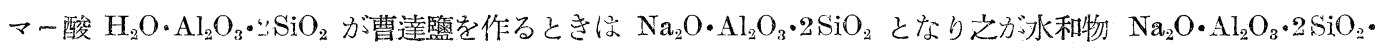
$\mathrm{H}_{2} \mathrm{O}$ を作るものと考へることが出來る。

斯く考へて來るとカオリナイトから得られるアルカリ攀土珪酸䜿水和物は次の 3 樣に考へられる。是等の 3 種と前節迄及び別報（前出）こに度々得た結果を見ると，生のカオリナイトを $\mathrm{NaOH}$ 溶液で加壓水熱處理を

$$
\mathrm{NS}_{2} \mathrm{O} \cdot \mathrm{Al}_{2} \mathrm{O}_{3} \cdot 2 \mathrm{SiO}_{2} \cdot \mathrm{nH}_{2} \mathrm{O}\left\{\begin{array}{l}
\mathrm{Na}_{2} \mathrm{O} \cdot \mathrm{Al}_{2} \mathrm{O}_{3} \cdot 2 \mathrm{SiO}_{2} \cdot 2 \mathrm{H}_{2} \mathrm{O} \\
\mathrm{Na}_{2} \mathrm{O} \cdot \mathrm{Al}_{2} \mathrm{O}_{3} \cdot 2 \mathrm{SjO}_{2} \cdot 2.25 \mathrm{H}_{2} \mathrm{O} \\
\mathrm{Na}_{2} \mathrm{O} \cdot \mathrm{Al}_{2} \mathrm{O}_{3} \cdot 2 \mathrm{SiO}_{2} \cdot \mathrm{H}_{2} \mathrm{O}
\end{array}\right.
$$

したときは多くは1.1〜1.3，時に 1.2〜1.4 位であつたが此の水は灼熱減量から得たので常に秒多く出勝ちで岗 るから之は略1.0に近いものと思はれたが前節の各溫度に报燒したメチカオリンを以つてするときは常に大き く 1.5 - 1.6, 時に 1.7 位になつて居て之も灼熱減量を給合水と見たので少し大きく出て居る樣で之は 1.2 - 1.3 位に見ると上記の 1.25 の式に近い樣である。是等の點から見てもカオリナイト，之觉煆燒したメタカオリン

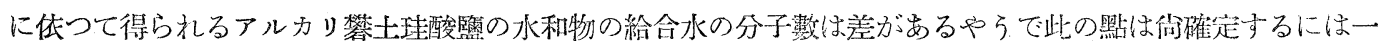
層の試驗砄究が必要であらふ。

因みにグリンマー酸水和物 $\mathrm{H}_{2} \mathrm{Al}_{2} \mathrm{Si}_{2} \mathrm{O}_{8} \cdot \mathrm{H}_{2} \mathrm{O}$ 又は $\mathrm{H}_{2} \mathrm{O} \cdot \mathrm{Al}_{2} \mathrm{O}_{3} \cdot 2 \mathrm{SiO}_{2} \cdot \mathrm{H}_{2} \mathrm{O}$ の樣にン分子の結合水に差を附 して考へるとカオリナイトを烺燒する場合初め $350^{\circ} \mathrm{C}$ 位の低い溫度で注意して熱すると少しの水郎ち 1 分子 の水が取れ酸, アルカリ液で溶け易くなり次に高く熱すると殕り 1 分子が除か礼ると云つて居ること(C. Bischof, Die Eeuerfesten Tone, 1923, 23) 點とよく合致する。

\section{(8) 要 旨}

磁土の主體であるカオリナイトは $\mathrm{Al}_{2} \mathrm{O}_{3} \cdot 2 \mathrm{SiOi} \cdot 2 \mathrm{H}_{2} \mathrm{O}$ の樣な示性式を有するものとされて居るのに近年で は之を $\mathrm{Al}_{2} \mathrm{O}_{3} \cdot 2 \mathrm{SiO}_{2} \cdot 1.5 \mathrm{H}_{2} \mathrm{O}$ とし殘る 0.5 分子の水は附着物とされ加熱中の脱水も 0.5 分子宛取れて $\mathrm{Al}_{2} \mathrm{O}_{3}$. $2 \mathrm{SiO}_{2} \cdot 1 \mathrm{H}_{2} \mathrm{O}, \mathrm{Al}_{2} \mathrm{O}_{3} \cdot 2 \mathrm{SiO}_{2} \cdot 0.5 \mathrm{H}_{2} \mathrm{O}$ を經て無水物となると考へる人もある。更に此の敘水物郎ちメタ・カオリ ンに就ても攀土と珪酸とが或る緩い結合にあって $\left(\mathrm{Al}_{2} \mathrm{O}_{3} \cdot 2 \mathrm{SiO}_{2}\right)$ で示し或は $\left(4 \mathrm{Al}_{2} \mathrm{O}_{2} \cdot 3 \mathrm{SiO}_{2}\right)$ で示し又は全く 遊離された樣に $\mathrm{Al}_{2} \mathrm{O}_{3}+2 \mathrm{SiO}_{2}$ で示して居るものもあつて攀士が酸に溶解し易く,珠酸がアルカリに溶解し易い 事薑, 更に此のメタ・カオリンを高溫度に加熱するとシリマナイト, Sillimanite, $\mathrm{Al}_{2} \mathrm{O}_{3} \cdot \mathrm{SiO}_{2}$ と遊離珠酸となり 一懕高い溫度でムライト, Mullite, $3 \mathrm{Al}_{2} \mathrm{O}_{3} \cdot 2 \mathrm{SiO}_{2}$ と遊離珠酸となり最後は是等各種の生成物から 1750 一 $1770^{\circ} \mathrm{C}$ で共融物が出來るとされて居る。此の攀土及び珪酸との結合の變化、酸アルカリに對寸る溶解性の變 化等を先づ第 1 に確め, 更に別報に於ける各種粘土に就てのアルカリ夜に依る加壓水熱處理の結果を待つて種 
ふの興味のある生成物を得て居るのて此のアルカリ液の加壓水熱處理法を適用して上述のカオリナイト，之を 各溫度に烺燒したメタ・カォリンに就て如何なる生成物を生ずるが究詳細に檢討寸る方法唯探つて此のカオリ ンの性狀に關する研究学開始したもので本報は其の第 1 報として今日迄に得た 2,3 の比較試驗結果を報告し たものである。

カオリンを $400^{\circ} \mathrm{C}$ から $1500^{\circ} \mathrm{C}$ 迄の各溫度に烺燒したものは $550^{\circ} \mathrm{C}$ 位から結合水の犬部分が除かれ、报燒 物中の攀土と珄酸とは稀い酸とアルカリとで容易に溶解し $900^{\circ} \mathrm{C}$ 迄の赈燒物では此の發出分離した結合水, 溶 解した攀土, 珪酸との間の分子比 $\mathrm{Al}_{2} \mathrm{O}_{3} / \mathrm{H}_{2} \mathrm{O}, \mathrm{Al}_{2} \mathrm{O}_{3} / \mathrm{SiO}_{2}$ は何れも $0.45 〜 0.55$ 郎ち $/ 2 の$ 近くの數值を取つて $\mathrm{Al}_{2} \mathrm{O}_{3} \cdot 2 \mathrm{SiO}_{2} \cdot \mathrm{H}_{2} \mathrm{O}(1: 2: 2)$ の分子比にあることを示し, 1000 - $1100^{\circ} \mathrm{C}$ 以上では急に攀士の溶出が少く, 珪酸は 寧ろ $1100 \sim 1300^{\circ} \mathrm{C}$ 附近は溶出汃霄すことから見ても $\mathrm{Al}_{2} \mathrm{O}_{3} \cdot \mathrm{SiO}_{2}+\mathrm{SiO}_{2}$ になり, $3 \mathrm{Al}_{2} \mathrm{O}_{3} \cdot 2 \mathrm{SiO}_{2}+\mathrm{nSiO}_{2}$ にな ることが起れる。

此の榐燒物を $\mathrm{NaOH}$ 溶液と共に加篹水熱處理を行ふと珪酸の溶出もなく, 生のカオリンと同じゃらに $\mathrm{Na}_{2} \mathrm{O} \cdot \mathrm{A}_{2}{ }_{2} \mathrm{O}_{3} \cdot 2 \mathrm{SiO}_{2} \cdot \mathrm{nH}_{2} \mathrm{O}, \mathrm{K}_{2} \mathrm{O} \cdot \mathrm{Al}_{2} \mathrm{O}_{3} \cdot 2 \mathrm{SiO}_{2} \cdot \mathrm{nH}_{2} \mathrm{O}$ 号作り, 全く遊離の攀土と珪酸とを $\mathrm{Al}_{2} \mathrm{O}_{3}: 2 \mathrm{SiO}_{2}$ に配合

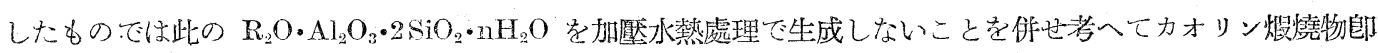
ちメタカォリン中の攀土と珪酸とは單に混合狀態に混在して居るのではなく何か特殊の結合狀態にもるもので 攀土が稀い酸液に溶け，䞍酸が稀いアルカリ夜に溶け易い形にあるばかりでなく更に禁土が此のアルカリ液で

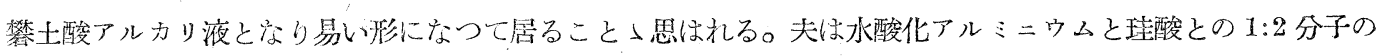
混合物 $\left[\mathrm{Al}_{2}(\mathrm{OH})_{6}: 2 \mathrm{SiO}_{2}\right]$ ならばカオリン，メタカオリンと同樣にアルカリ液の加壓水熱處理に估つて同樣の アルカリ鐢士珪酸鹽水和物を生ずること〉併せ考へると $1400 \sim 1500^{\circ} \mathrm{C}$ 以上に灼熱して $\alpha$ 及は $\beta$-Alumina にしたものはアルカリ液には難溶であつて $\mathrm{Al}_{2} \mathrm{O}_{3}: 2 \mathrm{SiO}_{2}$ 配合物からは此の生成物が得られなくて水酸化アル ミニウムはアルカリ夜で溶けるため $\mathrm{Al}_{2}(\mathrm{OH})_{6}: 2 \mathrm{SiO}_{2}$ 混合物からは容易に此の生成物穵生ずることなどから考 へてカォリン煆燒物中の攀土と珪酸とは單なる混合狀態にあるのではなくて特殊の性狀にあることを想像し得 るのである。

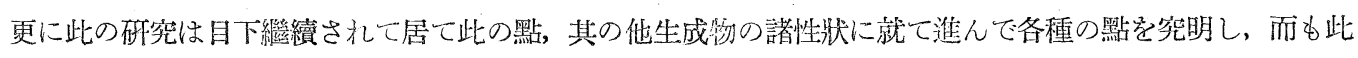
の生成物郎古 $x \mathrm{R}_{2} \mathrm{O} \cdot \mathrm{Al}_{2} \mathrm{O}_{3} \cdot y \mathrm{SiO}_{2} \cdot 2 \mathrm{H}_{2} \mathrm{O}$ の形を有し滞石族化合物と同樣の性狀を利用し又は其の攀上含有長石 型生成物としての用途に就ても各方面から試驗研究中であるから第 2 報以下に逐次報告しゃう。偷此の試驗研 究には助手渡邊勉君の終始熱心な實驗に依るところが多いことを明記して感謝の意を表したい。（昭 11.6.

13）(東京帝國大學工學部應用化學科珪酸䈑工業化學研究室) 